УДК 738. 1: 65.012.32(477)19-20

Школьна Ольга Володимирівна доктор мистеитвознавства, професор, Київський національний університет культури і мистецтв, Київ, Україна dushaorchidei@ukr.net

\title{
ЄВРОПЕЙСЬКО-АЗІЙСЬКІ ТРАНСФОРМАЦІЇ В ТВОРЧОСТІ ОПШШНЯНКИ ЄЛИЗАВЕТИ ТРИПІЛЬСЬКОЇ
}

Творчість спадкоємниці Зіньківського маєтку Єлизавети Трипільської, котра виробила свою власну стилістику авторської скульптури та зразків промислової кераміки завдяки синтезуванню набутків українського традиційного гончарства $з$ одного боку, а з іншого - європейського академічного рисунку, живопису й пластики, яка $є$ унікальна. Завдяки урокам Огюста Родена та багатьох класиків епохи символізму, модерну й ар деко, мисткиня опанувала різні техніки, матеріали в скульптурі малих форм i, завдяки специфічній декоративності, що іноді межувала 3 натуралізмом, виробила свою власну манеру в радянській порцеляновій фігурці кінця 1920-х - початку1930-х рр.

Мета - проаналізувати становлення й розвиток пластичної мови скульпторки першої пол. XX ст. Слизавети Трипільської, творчий спадок якої належить Україні, Росії та Азербайджану. Методологію дослідження становлять історико-культурний метод (для виявлення складових творчого почерку скульпторки); історико-порівняльний метод (для осягнення здобутків Єлизавети Трипільської в радянському фарфорі та станковій скульптурі радянських республік, на території яких впродовж першої пол. XX ст. їй довелося працювати); метод теоретичного узагальнення (для інтерпретації рис іiі творчості в кераміці, зокрема, тонкій та ін. матеріалах); метод мистецтво знавчого аналізу (для виявлення ознак художньої творчості мисткині). Наукова новизна роботи полягає в систематизації основного творчого доробку Єлизавети Трипільської, яка, маючи дворянське походження, змушена була довгий час працювати за межами України та повернути призабуті чи втрачені знання про життя й творчість мисткині до вітчизняної художньої культури. Висновки. На основі проведеного дослідження вдалося проаналізувати життєвий та творчий шлях видатної скульпторки Єлизавети Трипільської, через перипетії якого відбувалася трансформація пластичної мови авторки. Враховуючи те, що мистецька спадщина скульпторки довгий час була розпорошена по щонайменше 
трьох країнах Свропи та Азії, тільки на початку XXI ст. вдалося укласти перелік з близько тридцяти основних робіт майстрині, частина яких належить до найбільших здобутків високого фарфору доби ар деко в Радянському Союзі.

Ключові слова: Слизавета Трипільська, Опішне, порцелянова фігурка, ар деко.

Школьная Ольга Владимировна доктор искусствоведения, профессор, Киевский национальный университет культуры и искусств, Киев, Украина

\section{Европейско-азиатские трансформации в творчестве опошнянки Елизаветы Трипольской}

Творчество наследницы Зеньковского имения Елизаветы Трипольской, которая выработала свою собственную стилистику авторской скульптуры и образцов промышленной керамики благодаря синтезированию достояний украинского традиционного гончарства с одной стороны, а с другой европейского академического рисунка, живописи и пластики, в своем роде уникальна. Усвоив уроки Огюста Родена и многих классиков эпохи символизма, модерна и ар деко, мастер подчинила разные техники, материалы в скульптуре малых форм и, благодаря специфической декоративности, которая иногда граничила с натурализмом, создала свою собственную манеру в советской фарфоровой фигурке конца 1920-х - начала 1930-х гг.

Цель - проанализировать становление и развитие пластического языка скульптора первой пол. XX ст. Елизаветы Трипольской, творческое наследие которой принадлежит Украине, России и Азербайджану. Методологию исследования представляют историко-культурный метод (для выявления составляющих творческого почерка скульптора); историко-сравнительный метод (для выявления достижений Елизаветы Трипольской в советском фарфоре и станковой скульптуре советских республик, на территории которых в течение первой пол. $\mathrm{XX}$ ст. ей пришлось работать); метод теоретического обобщения (для интерпретации черт ее творчества в керамике, в том числе тонкой, и других материалах); метод искусствоведческого анализа (для выявления признаков художественного творчества мастера). Научная новизна работы состоит в систематизации информации относительно основного творческого наследия Елизаветы Трипольской, которая длительное время из-за своего дворянского происхождения вынуждена была работать за пределами Украины, и возвращения знаний о нем отечественной художественной культуре. Выводы. На основе проведенного исследования удалось проанализировать жизненный и творческий путь выдающегося скульптора первой пол. ХХ ст. Елизаветы Трипольской, изза перипетий которого происходила трансформация пластического языка автора. 
Учитывая то, что художественное наследие скульптора длительное время находилось в по меньшей мере трех странах Европы и Азии, только в начале XXI ст. удалось создать перечень около тридцати основных работ мастерицы, часть которых принадлежит к наивысшим достижениям высокого фарфора поры ар деко в Советском Союзе.

Ключевые слова: Елизавета Трипольская, Опошня, фарфоровая фигурка, ар деко.

Shkolna Olha Doctor of Arts Study, Professor, Kyiv National University of Culture and Arts, Kyiv, Ukraine

European and Asian transformations in the creative work of the inhabitant of Opishnia village Yelyzaveta Trypilska

The creative work of the heiress of the Zinkiv manor Yelyzaveta Trypilska, who developed her own style of original sculpture and samples of industrial ceramics through the synthesization of works of traditional Ukrainian pottery on the one hand, and European academic drawing, painting and plastics on the other, is unique. Owing to Auguste Rodin's lessons and learning from many fathers of symbolism, Art Nouveau and art deco, the artist mastered different techniques, materials of smallscale sculpture and, through the specific decorative effect, which sometimes verged on naturalism, developed her own manner in Soviet porcelain figurines of the late 1920's - early 1930's.

The purpose of the article is to analyze the formation and development of the plastic language of the sculptor of the first half of the $20^{\text {th }}$ century Yelyzaveta Trypilska, whose creative heritage belongs to Ukraine, Russia and Azerbaijan. The research methodology consisted in the historical and cultural method (to distinguish the components of the sculptor's idiom); the historical-comparative method (to comprehend the achievements of Yelyzaveta Trypilska in Soviet porcelain and easel sculpture of republics of the Soviet Union, where she worked during the first half of the $20^{\text {th }}$ century); the method of theoretical generalization (to interpret the features of her work in ceramics, including fine ceramics, and other materials); the method of art critical analysis (to identify the signs of the master's creative work). The scientific novelty of the work lies in the systematization of the basic creative heritage of Yelyzaveta Trypilska, who, being of noble birth, was compelled to work outside Ukraine for a long time, and the recovery of lost or forgotten knowledge concerning the life and creative work of the artist in domestic art culture. Conclusions. The research provided for the analysis of the life and career of the outstanding sculptor of the first half of the $20^{\text {th }}$ century Yelyzaveta Trypilska, through which the plastic language of the artist was transformed. Given the fact that the art 
heritage of the sculptor was scattered across at least three countries of Europe and Asia for a long time, only at the beginning of the $21^{\text {st }}$ century was it possible to create the list of about thirty basic works of the master, part of which belong to the greatest achievements of fine porcelain of art deco in the Soviet Union.

Key words: Yelyzaveta Trypilska, Opishnia, porcelain figurine, art deco.

Постановка проблеми. У цілому в українській скульптурі початкуXX ст. відомо декілька імен видатних жінок, які пройшли студіювання за кордоном, переважно в Франції. У Львові - це Люна Дрекслер, у Харкові - Леонора Блох і згодом Жозефіна Діндо, в Москві й Петербурзі - Аліса Брускетті-Мітрохіна, у Петербурзі та Києві - сестри Наталка та Олена Данько, на ЧернігівщиніСумщині - Слизавета Скоропадська, на Полтавщині - Слизавета Трипільська. $€$. Скоропадська та $€$. Трипільська були представницями шляхетних родин, які натомість меценатству обрали творчий шлях. Адже родинними маєтками першої Слизавети були землі славного Зенькова з Опішнею в підпорядкуванні, а другої - всесвітньовідомого «порцелянового» Волокитина, що належав дружині останнього українського гетьмана.

Обгрунтування наукової проблеми та її зв'язок із важливими науковими чи практичними завданнями. Ім'я визначної скульпторки-опішнянки Єлизавети Трипільської належить до когорти митців-універсалів, народжених наприкінці XIX ст. задля реформацій в мистецтві не лише українському, а й світовому. На сьогодні варто повноцінно ввести їі ім'я до вітчизняного, європейського, азійського наукового обігу, зважаючи на мистецький рівень залишеної авторкою спадщини. Враховуючи, що в творчості цієї керамістки знайшли місце як любов до пластичного моделювання в глині, прищеплена в дитинстві на Полтавщині, так і виразні імпульси європейського світського мистецтва й колориту азійського пістрявого етнографізму, що увиразнює надбання $Є$. Трипільської серед кращих світових авторів фарфорової скульптури доби ар деко. Адже не зважаючи на всі досягнення мисткині, на жаль, іï творчість не стала предметом окремого наукового дослідження.

Аналіз останніх досліджень і публікацій. Доля художниці світового рівня в царині порцеляни, майстра мармуру, гіпсу й бронзи, була водночас типовою для своєї доби й мала власні метаморфози розвитку. Тільки через 50 років після спочинку Є. Трипільської, етапи діяльності цієї жінки поступово стають надбанням співвітчизників. Повноцінне й всебічне дослідження спадщини Слизавети Трипільської стало можливим лише за умов каталогізації та висвітлення творів, що тривалий час знаходились у приватних колекціях і музеях (зокрема, фондах) виробництв Ломоносовського фарфорового заводу 
(нині Санкт-Петербург) і Вербілок (Підмосков’я). Після публікації верифікованих даних відносно цих двох основних, а також інших збірок російської порцеляни, групою вчених на чолі з Ельвірою Самецькою 2004 р. [13; 14], дало змогу усвідомити рівень і масштаб творчості Слизавети Трипільської, зважаючи на доробок найяскравішого мистецького періоду життя, який був пов'язаний з російськими виробництвами фарфору епохи арт деко.

Виділення раніше не вирішених частин загальної проблеми. Сьогодні надзвичайно важливо повернути ім'я українки Єлизавети Трипільської (Трипольської за російським та англійським транскрибуванням) вітчизняній художній культурі. Так сталося, що через замовчування iї справжнього життєвого й творчого шляху, представники інших країнах сьогодні претендують на одноосібне володіння іï спадщиною, хоча мисткиня стала заручницею політичного вигнання й у певній мірі «декабристкою» свого часу.

Мета даної статті - узагальнити та систематизувати художній доробок Єлизавети Трипільської, окреслити основні здобутки непересічної скульпторки радянського фарфору XX ст.

Виклад основного матеріалу дослідження. Починаючи 3 дати й місця народження, які за різними джерелами коливаються в межах 19(31).11.1881, Полтава [25] або 1883 р., Опішне на Полтавщині [1, 111] - 6.11.1958 [22], Баку, віхи життя Слизавети Трипільської (за першою варіацією Олени Пчілки 1913 року - Катерини Трипольської) [3] сповнені розбіжностей та протиріч. За різними версіями біографії, мисткиня по-батькові була Романівна [1], Родіонівна [25], Іларіонівна [13], прізвище також транскрибувалося, мабуть, після поїздки до Франції, у три різні модифікації: Трипільська [25], Трипольська [10; 16], Троєпольська [16].

Трипільські були поміщиками Опішного. За деякими даними, дядьком Слизавети був відомий український пейзажист Михайло Іванович Холодовський (1855-1956 рр.) [25; 9]. Він навчався живопису в художників В. Волкова й І. Зайцева. У 1875 р. закінчив військове училище у Петербурзі, жив та працював у своєму маєтку під Лубнами. За його пейзажами на українську тематику було надруковано багато поштівок. Твори дядька $Є$. Трипільської як відомого передвижника експонувалися на багатьох виставках Російської імперії. M. I. Холодовський, названий В. В. Стасовим серед кращих пейзажистів I. І. Левітаном, В. О. Волковим, І. С. Остроуховим, був одним із засновників Київського товариства художників (1916-1918 рр.), дійсним членом Товариства художників-киян (1914-1919рр.). Твори митця зберігаються в Національному художньому музеї України, багатьох державних та приватних колекціях. Цікавою обставиною є той факт, що для збірки Прилуцького музею пейзаж М. І. Хо- 
лодовського В. І. Маслов придбав у Будах Харківської області, місцевості, де знаходилася найбільша фабрика фаянсу (до 1904 р. й фарфору) в Україні Товариства Кузнєцових. Можливо, художник виїздив туди на пленер [9].

Дитинство майбутньої знаної скульпторки проходило в атмосфері тісного спілкування з повним спектром народного гончарства, характерного для Полтавської землі й, зокрема, Опішного, професійною керамікою і їі різновидами посудних форм, пластикою, промисловими зразками кахлів, дахівки, труб; творами високого живопису й специфічної мистецької атмосфери краю (Рис. 1).

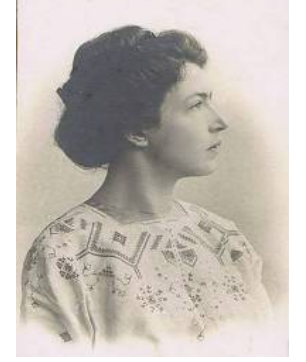

Рисунок. 1. Слизавета Трипільська - поміщиця Опішного, Зінькова, випускниця Полтавського інституту шляхетних панянок 1896 р., керамістка й майбутня скульпторка, відома на кількох континентах.

Не дивно, що з часом потяг до малярства й скульптури переріс із зацікавлення у сенс життя юної Лізи. Мабуть, за рекомендацією дядька племінниця потрапляе саме до викладача й однодумця М. I. Холодовського [24], який на той період викладав у Полтаві.

У В. О. Волкова в Полтавському інституті шляхетних панянок дівчина здобула початкову професійну художню освіту, продовжила студіювання мистецтва пластики від 1897 р. у майстернях скульпторів Л. В. Шервуда, В. О. Беклемішева [25], Р. Р. Баха [22]; у Петербурзькій художній школі Товариства заохочування митців; у графіків А. Ф. Ціонглінського, Д. М. Кардовського в Петербурзі. У 1903 р. вже приймала участь у виставці в Полтаві [9]. На гроші, отримані за виконання для Полтави скульптурної групи для водограю на площі перед Земським будинком (так і не був встановлений), Єлизавета Трипільська їде до Парижу. Гіпсовий ансамбль був проектом, виконаним на замовлення Полтавської губернської управи 1906 р. Сюжет передбачав зустріч дівчини-українки з відрами та красеня-водяника, що раптово перегороджував їй дорогу, набирав воду до рота і жартома запускав струмінь у свою супутницю [25].

Після завершення роботи над цією скульптурною групою, С. Трипільська удосконалює свою майстерність у більш тривких матеріалах і продовжує навчання в студії Н. Аронсона та в майстерні В'єжаля (1906-1907 pp. [22]). Сповнена натхнення, художниця прагнула втілити модель групи із зображенням дівчини-українки й красеня-водяника для водограю перед будинком Полтавського земства 1907 р. [18]. 
Виконані впродовж 1904-1909 рр. «Селяни», «Водяник», «Портрет хлопчика» та «Цокотуха» (останні роботи датуються 1908-1909-ми рр., згодом за них мисткиня отримала Куїнджівську премію [22]), були вперше виставлені 1909 р. на виставці в Києві, як і теракотові (керамічні) погруддя дівчат, молодиць (Рис. 2),

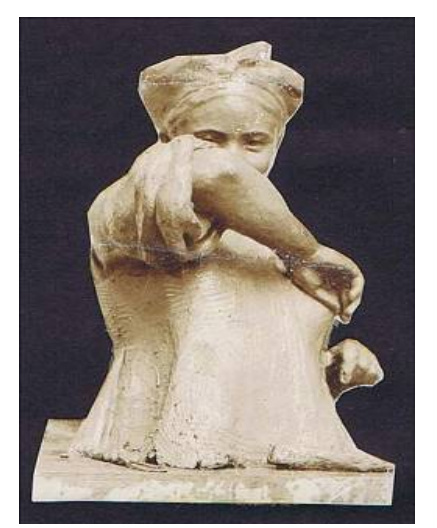

Рисунок 2. Ранній «етнографічний» період творчості Слизавети Трипільської. Бюст «Молодиця». Світлина з родинного архіву Трипільських. США - Ізраїль.

«Англійський тхір» (бронза, 1910), «Голівка дитини» (1910, мармур), «Засоромилась», «Паніматка» [18], «Дядько Кривоніс» (всі - 1910-й, глина) стали справжніми подіями мистецького життя України 1910-х рр. 1912-го р. $€$. Трипільська виконала твори «Панна» (гіпс) і «Селянин». Наступні, післявоєнні твори скульпторки з'являються в 1916-1917-му рр. в бронзі - «Билиночка», «Жартує», «Катерина» та у 1918-му р. були виконані проект «Українське весілля» для опішнянських гончарів, майолікова група - «На ярмарку» [21]. У біографії скульпторки лишаються «загубленими» кілька років, коли вона перебувала в зеніті розквіту сил - між 28-33 pp. Можливо, п’ятиріччя було витрачене на засвоєння технологій в напрямку фарфор-фаянс-майоліка (останній твір частково це підтверджує).

«Творча тиша» 1911-1915 pр. може бути пов'язана з україно-російськофранцузькими зв'язками художниці. Зокрема, відомо, що з 1913 р. Є. Лансере, визначний «міріскуснік», запрошений очолювати художню частину Імператорського фарфорового заводу. Разом із ним до підприємства приходить С. Судьбінін. Захоплення оперними та балетними сезонами Франції, до постановок яких мав відношення інший член гуртка Л. Бакст, призводить до введення до образного ряду дрібної фарфорової пластики ІФЗ костюмованих персонажів модних опер і балетів. С. Судьбінін для статуетки балерини Т. Карсавіної ліпить голову героїні з натури в Парижі, в Лондоні опрацьовує з натури три образи А. Павлової - в «Жизелі», «Вакханалії» та «Лебеді». 
На зміну карикатурних шаржів до мистецтва фарфору вриваються колоритні образи, ліплені з живих людей. Особливо цінується емоційне враження, рух у пластичній формі, що приходять на зміну зашкарублим «мундирним» постановкам та етнографічним серіям. Саме з 1913 р. художня частина ІФЗ скеровується на пошуки самостійного національного стилю [2, 35-36], з векторами до зближення з одного боку із Заходом, насамперед, Францією (ар нуво, а згодом ар деко зі специфічною декоративністю) та головним спрямувавнням у бік Сходу з тканинними візерунками й ошатністю східних танцівниць, екзотикою Середньої Азії та Закавказзя.

Перед тим цю останню сюжетну лінію на межі XIX - початку XX ст. почали відпрацьовувати на Будянській філії Товариства Кузнецових. Вихід на ринок подібного товару був пов'язаний з отриманням замовлень на поставку товарів так званого «азійського асортименту» до Китаю, Сирії, Персії, Азербайджану, Туркменії. Врешті-решт, маючи добрий прибуток, Товариство Кузнецових настільки якісно засвоїло випуск сегменту товарів, який йшов на експорт, що вироби «концерну» сприймались більш «китайськими», ніж тамтешні, місцеві.

Успіх такого фабрикату пов'язаний 3 розробками на всіх філіях ТоваРиства та засвоєнням принципів східного формотворення й оздоблення порцеляни та фаянсу майстрами різних спеціалізацій. Частина $з$ кваліфікованого кузнецовського персоналу на початку XX ст. перейшла працювати до полтавських осередків з вивчення виготовлення мистецьких порцеляни-фаянсумайоліки - передусім, до Миргорода й Опішного. Зрозуміло, що засвоєння нових композиційних прийомів i схем декорування виробів, привнесене викладачами-майстрами 3 Буд, спрацьовувало в сенсі зацікавлення на всю творчу спільноту краю. Тобто, цілком ймовірно, що вивчення Слизаветою Трипільською законів побудови «східно орієнтованої» екзотичної скульптури малих форм у 1910-х р., мало не спонтанний характер.

Варто зазначити, що в 1914 р. С. Лансере запрошує для постійної роботи на Імператорському фарфоровому заводі скульпторів В. Кузнецова та Н. Данько, котрі перед тим розробляли неокласичний напрямок монументальнодекоративної модерної пластики [12] у Петербурзі, Москві та Києві, співпрацюючи з архітекторами В. Щуко, І. Фоміним, Ф. Лідвалем, А. Тамановим [2, c. 37]. Свій напрямок у фарфоровій скульптурі, яка користувалася іншими засобами виразності, ці митці знайшли не одразу. Проте, існування даної когорти майстрів у певний період часу в творчих колах України, можливе спілкування 3 архітектором Василем Кричевським, дотичним до творення Полтавського земства, в розробці ансамблю якого брала участь скульптор Слизавета Трипільська, могло спричинити взаємозбагачувальні контакти майбутніх зірок радянської порцеляни, твори яких певною мірою стилістично пов'язані. 
На період відвідування мисткинею майстерні Н. Аронсона, реформатор скульптури Огюст Роден саме в цей час завершував працю над епохальним твором «Громадяни Кале». Слизавета Трипільська була присутня під час відливання роботи, яка на неї справила незабутнє враження. Майстриня пам'ятала цю зустріч все життя [7]. У Парижі скульпторка також уважно вивчала техніку праці з мармурами. Згодом ії скульптурні портрети, виконані в Франції й експоновані надалі на виставці в Петербурзі, мали прихильників серед російських критиків [1, с. 111]. Упродовж 1904-1917 рр. Слизавета Трипільська працювала в різноманітних матеріалах - гіпсі, мармурі, бронзі [21]. 3 українських типів цікавою $є$ іiі твір «Завзята». Твори мисткині поступово ставали відомими, зокрема «Бюст пана Т.», гіпсові етюд «Свиня», скульптура «Осетин» 1912 р. На початку століття Є. Трипільська виконала почесне замовлення - барельєф для пам'ятника Катерині II у Єкатеринбурзі. 1918-го р. пластик спробувала свої сили в майоліці. Надалі іiі чекало творче життя в фарфорі. Деякі факти відносно праці авторки в означений період вдалося встановити за листуванням Дмитра Яворницького [15]. Серед останнього збереглися листи Сергія Васильківського, Іллі Рєпіна, Слизавети Трипільської. За цима джерелами відомо, що в 1912 року вона перебувала в Петербурзі, a 1915, 1918 рр. писала до відомого історика Дмитра Яворницького з власної садиби Зінькова Полтавської губернії. Зокрема, у фондах Дніпропетровського національного історичного музею збереглися три листи, за відповідними датами. У першому з них скульпторка дає своєму респонденту згоду на виконання власного проекту пам'ятника Катерині II у Катеринославі (тепер - місто Дніпро) та цікавиться його думкою відносно ідеї розробки. 3 листа випливає, що Слизаветі Трипільській була потрібна допомога в підборі матеріалу щодо портретів оточення монархині, оскільки концепція пам'ятника передбачає барельєфні зображення сподвижників імператриці на постаменті пам'ятника (ДНІМ, Арх-20914) [3].

Другий лист стосується відкриття цієї скульптурної групи й присутності на церемонії Дмитра Яворницького (від 02.01.1915 р.). Згадуючи події того дня, Єлизавета Трипільська піклувалася про долю бюсту Дмитра Яворницького, який вона виліпила з гіпсу й пропонувала історику надіслати модель до школи Гоголя в Миргороді, оскільки там вона вже домовилася відтворити його в теракоті. Надалі мисткиня передбачала, що по закінченні війни буде намагатися відлити цей скульптурний портрет у бронзі, як замовлялися від самого початку (ДНІМ, Арх-20913). Цей гіпсовий бюст (ДНІМ, Х-766) зберігся. На думку дослідниці даного питання у Дніпропетровському національному історичному музеї В. В. Буряк, є підстави вважати, що Дмитро Іванович настільки цінував твір видатного пластика, що в ті буремні часи не став ризикувати й надсилати роботу до Миргороду, боячись її втратити [3]. 
За спостереженнями Д. Н. Наврузової, азербайджанського бібліографа Є. Р. Трипільської, творчість скульптора протягом 1908-1918 рр. відзначалася бентежними образами, підказаними життям. Знайомство $з$ відомим істориком у Полтаві й спільна праця над втіленням ідей 1912-1914 рр. згодом стали запорукою вдалого портрету Д. І. Яворницького [3]. Завдяки порадам видатного Д. І. Яворницького, Є. Р. Трипільська створила цілу низку історичних образів українців, які експонувалися на виставках у Петербурзі, Москві, Києві, Сочі, Ленінграді й Баку [3].

Так, у фондах Дніпропетровського національного історичного музею імені Д. Яворницького зберігаються чотири бюсти відомого історика, авторство трьох після 1945 р. не було встановлено. За останнім з наведених листів Є. Р. Трипільської й спогадами співробітника музею О. М. Огризкіної, є підстави стверджувати, що бюст Д. І. Яворницького, виконаний в гіпсі (ДНІМ, КП-9863, X-766) - це саме той скульптурний портрет, а не «копія», як вважалося раніше, виконаний автором 1914 р., що не був відлитим із бронзи [3; 13].

1915 р. пластик завершила бюст артиста Юрьєва, який експонувався на пересувній виставці в Москві, а згодом був переданий до збірки музею імені Бахрушина в цьому ж місті. Надзвичайно складний економічний стан 19151918 рр. і від'їзд 1919 р. Є. Р. Трипільської з України стали на заваді здійснення цього задуму. Згаданий бюст у якості власної меморіальної речі зберігався в Дніпропетровську в будинку на Жовтневій площі до 1946 р. [3].

3 початку радянської влади $€$. Трипільська за автобіографічними нотатками викладала на курсах сільських вчителів у Полтаві, працювала при музеї з питань охорони пам'яток мистецтва. Після жовтневої революції Слизавета Трипільська повернулася до України й працювала як скульптор в основному в Полтаві та Києві, де створила численні портрети й жанрові композиції, в яких були ще відчутні Риси імпресіонізму [1, с. 111]. Особливістю їі творчості цього періоду була своєрідна манера, яка межувала одночасно $з$ етнографізмом i натуралізмом. Авторка зверталась до різних технік і жанрів, експериментувала одночасно 3 керамікою, станковою скульптурою, цікавилась промисловими формами порцеляни та фаянсу. У цей час гончарями з Опішного за ії ескізами були створені ляльки «Українське весілля» [25], які увійшли до історії вітчизняної керамології.

У 1920-х рр. здібна мисткиня універсального творчого діапазону була відряджена ВХУТЕІНом [3] до Баку. Можливо, стажування поєднувалось з навчанням у Вищому художньо-технічному інституті, оскільки за даними російського мистецтвознавця Е. Самецької, художниця закінчила саме цей заклад, відкритий в Петербурзі 1922 р. на підвалинах Академії мистецтв. 
31923 р. Слизавета Трипільська проживала в столиці Азербайджану, виконувала барельєфи та горельєфи «Землеробство», «Музика», «Прометей», «Наука» для столичних інтер'єрів Академії Наук Азербайджанської РСР (19231925 рр.); фігуру робітника до пам'ятника 26-ти бакинським комісарам [25] у Баку (1923-1924 р., не зберігся [9]). У 1924 р. авторка долучилася до проектування воріт на складі Азнафти. Єлизавета Трипільська працювала й в інших творчих відрядженнях: як зазначає Н. Ю. Асєєва, мисткиня була автором моделі пам'ятника В. І. Леніну (1926-1927 pp., бронза, кераміка), встановленого 1927 року в Ашхабаді [1, с. 111], столиці Туркменської РСР (у співавторстві) [9], де втілила ідею постаменту з мотивами кількох основних типів традиційних таджицьких килимів.

Не перебуваючи в штаті Ломоносовського фарфорового заводу, Слизавета Трипільська виконала для нього кілька скульптур [9; 17]. Протягом 19261928 pр. скульпторка здебільшого працювала в Ашхабаді. Але за даними Центрального державного архіву народного господарства СРСР, у переліку фарфорових виробів Державного порцелянового заводу, прийнятих на ювілейну виставку Мосради 18 листопада 1927 року, під № 55, значиться фігура «Східної жінки», Рисунок Є. Трипільської [17, с. 251-253]. Тобто один 3 варіантів відомої «Афганки», що є водночас одним 3 кращих творів зрілої Єлизавети Трипільської, міг бути виготовлений вже наприкінці поточного року. (Іноді скульптуру називають «Бакинка» або «Азербайджанка», але в оригінальному варіанті, зважаючи на авторський розпис, за якого фігура жінки в яскравому одязі стоїть на вимальованому клаптику землі із назвою Афганістан, «Афганка») (Рис. 3).

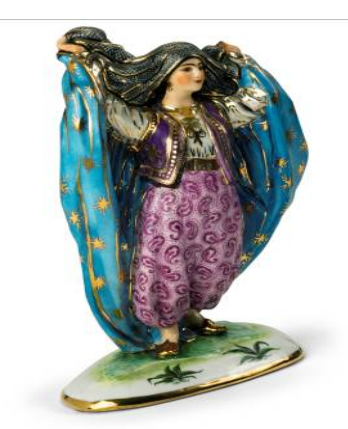

Рисунок 3. Трипільська Є. Р. «Східна жінка, що знімає чадру» («Афганка»). Варіант розпису. ЛФЗ. Кінець 1920-х - початок 1930-х рр. Фарфор, надглазурний розпис. Приватна збірка.

3 1927-го р. прізвище Єлизавети Трипільської, вірогідно в якості ще студентки ВХУТЕІНу, зустрічається серед оціночних відомостей моделей Ломоносовського фарфорового заводу. Зокрема, відомі авторські варіації розфарбування порцелянової скульптури «Афганка» («Східна жінка, закутана 
в чадру» й «Східна жінка, що знімає чадру») та композиція «Східний носій (Амбал)». На користь 1927 р. свідчить рукопис скульптора заводу Б. Савицького із рисунками пером, знайдені І. А. Крюковою, про що зазначає Е. Самецька. 1927-1928-ми р. датуються й розціночні відомості ЛФЗ щодо останньої 3 перелічених робіт. Обидва згадані твори, а також «Азербайджанка в чадрі» та ін. були виконані скульпторкою за даними іï автобіографії протягом 19231925 рр. на Дмитровському фарфоровому заводі для Ломоносовського фарфорового заводу [20; 8 , с. 359].

Також 1928 р. позначені протоколи художньої ради живописної та скульптурної майстерень ЛФЗ, що фіксують чотири рисунки Слизавети Трипільської, вислані на завод як варіанти декоративного оздоблення роботи «Східна жінка, що знімає чадру» [13] (в автобіографії мисткині значиться, що цьогоріч вона поновила працю над цією скульптурою). У подальшому три вище названі вироби авторки будуть датовані 1929 р., коли вони були занесені до альбому зразків [13]. Можливо, твори були доопрацьовані й прийняті до масового виробництва вже після співпраці Єлизавети Трипільської з Дмитровським фарфоровим заводом у Підмосков"ї, куди художниця спрямовувала свої мистецькі здібності протягом 1928-1933 рр. [25].

У більшості з відомих видань, ці, без перебільшення епохальні парні «Афганки», що мають ідеологічну маніфестацію емансипації східного жіноцтва з одного боку, та несли в світ яскраву феєрію орієнтального узороччя ар деко з іншого, наводяться як роботи ще однієї українки, Наталі Данько. Це пов'язано із декоративною манерою виконання творів, дійсно, близькою почерку двох наших співвітчизниць, які також пройшли французьку школу - Аліси Брускетті-Мітрохіної (1872-1942рр.), відомої лише кількома творами («Буржуйка, яка продає речі», вона ж «Перекупка» або «На ринку», й «Дама, що сидить у кріселку») та тандему сестер Олени (1898-1942 pp.) і Наталі (18921942 рр.) Данько [11, с. 86-87]. Слизавета Трипільська (1881-1958 рр.) була четвертою серед цих «каріатид-стовпів» радянського мистецтва європеїзованої порцеляни, що пройшли французьку школу, однак стадіально іiі творчість припадає на кінця1920-х - початку1930-х рр., коли перші три художниці вже протягом десятиліття перебували в зеніті слави.

Протягом 1928-1933 pp. Слизавета Трипільська в період праці на Дмитровському фарфоровому заводі у Вербілках, серед іншого, створила так звані «Туркменські шахи» (Рис. 4, 5), авторство яких датується 1928 р., 

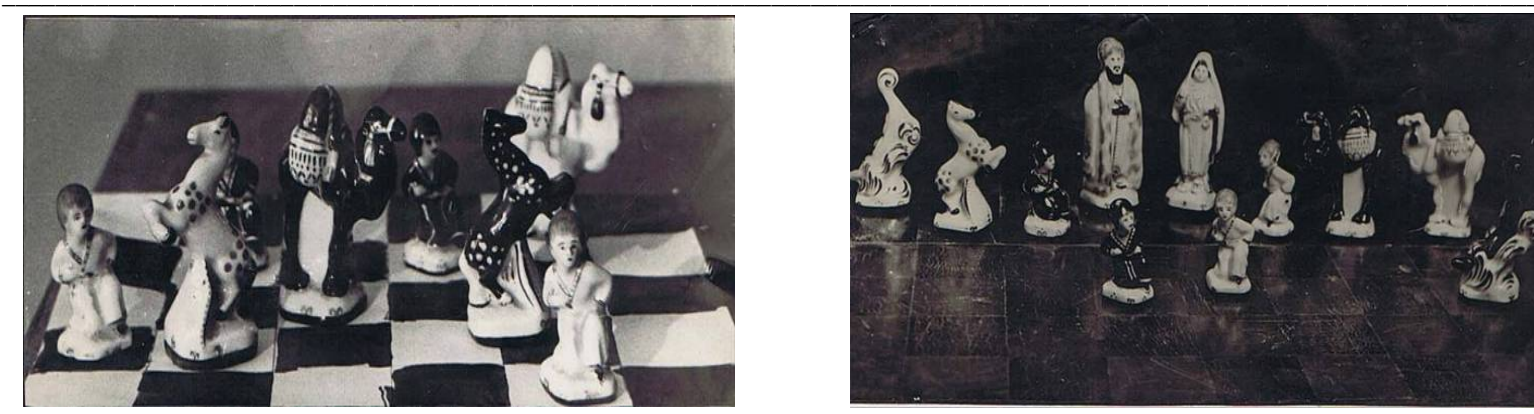

Рисунок 4 i 5. Фарфорові шахи «Туркменські» авторства Єлизавети Трипільської.

Дмитровський фарфоровий завод. Унікальні світлини подарунку кращого досягнення радянської промисловості доби індустріалізації від Уряду Радянського Союзу президенту США Ф. Рузвельту 1928 р. Архів племінника Слизавети Родіонівни Трипільської Олега Володимировича Трипільського та його нащадків. Світлина надана внучатим племінником скульпторки, відомим архітектором США та Ізраїлю Волею Трипільським.

один примірник яких був подарований радянським урядом президенту США Ф. Рузвельту [25]. Можливо й понині десь у американських колекціях Білого Дому або в муніципальних збірках Вашингтону зберігається часточка доробку визначної опішнянки Слизавети Трипільської, творчість якої була варта міжконтинентальних дипломатичних відносин.

Мабуть, з 1928-1929 рр. скульпторка виконувала періодично творчі замовлення підприємства. Відома статуетка «Українка» (1929 р.) [9], запроектована Єлизаветою Трипільською, очевидно на базі Вербілок, де вона працювала в штаті протягом 1931-1933 pp. [25]. Хоча збереглися дані, де в 1929 р. художниця стала співробітницею Дмитровського фарфорового заводу. Як зазначає дослідник російської порцеляни Вербілок М. В. Чорного, лише в 1931 p. ВХУТЕІН відрядив на Дмитровський фарфоровий завод когорту художників у складі В. Васильєва, П. Кожина, А. Траскунова, Є. Трипільської [26; 27, с. 145], художника з української Баранівки Т. 3. Подрябіннікова.

Колективом прибулих авторів було створено близько 30 зразків розпису чайного посуду, що віддзеркалювали революційні події та нову побутову культуру радянської доби (переважали зображення робітниць у хустинах, робітників з молотом, тракторів, верстатів). Проте, торговельні організації відмовились замовляти посуд 3 таким оформленням [4; 5]. Тим не менше, збереглася низка скульптурних робіт авторки в порцеляні, завдяки яким вона стала відома на весь колишній Радянський Союз.

Наведемо їх перелік: 1,2,3. «Азербайджанка в чадрі», «Азербайджанка, що знімає чадру», «Амбал». 1923-1925 рр. Фарфор, надглазурний розпис. 4. «Азербайджанка, що знімає чадру». 1928 р. Фарфор, надглазурний розпис. 5. «Туркменські шахи». 1928 р. Фарфор, надглазурний розпис. 6. «Українка з дитиною на руках». 1929 р. 7. Фарфор, надглазурний розпис. Збірка Державного 
музейного комплексу Москви «Кусково». Фарфор, надглазурний розпис. 8. «Дівчина в українському костюмі». 1929 р. Фарфор, надглазурний розпис. Збірка Державного музейного комплексу Москви «Кусково». 9. «Дівчинка з кубиками». 1929-1930 рр. Бісквіт, розпис. Збірка Талдомського краєзнавчого музею Дмитровського району Московської області. 10. «Дівчинка з м'ячем». 1929-1930 pр. Бісквіт, розпис. Збірка А. А. Добровінського. 11. «Делегатка». 1929 р. Бісквіт, розпис. Збірка ВМДПНМ (Всеросійського музею декоративноприкладного й народного мистецтва). 12. «Лижниця», створювалась за даними авторки протягом 1928-1933 pp. 1929-1930 pp. Бісквіт, розпис. Збірки А. А. Добровінського, Державного музейного комплексу Москви «Кусково», Талдомського краєзнавчого музею Дмитровського району Московської області. 13. «Лижник» (скульптура, парна до «Лижниці»). 1929-1930рр. Бісквіт, розпис. Збірка Талдомського краєзнавчого музею Дмитровського району Московської області. 14. «Прикордонник з біноклем, що стоїть біля прикордонного стовпа із написом: „СРСР”». 1931 р. Бісквіт, розпис. Збірка ВМДПНМ. 15. Підставка для олівців 3 фігурою прикордонника із біноклем у руці. 1930-ті рр. На підставці для олівців напис: «Нам чужой земли не нужно не одной пяди, но и своей земли ни одного вершка не отдадим». Фігура прикордонника виконана за моделлю 1931 р. Фарфор, надглазурний розпис, позолота. Збірка А. А. Добровінського. 16. Підставка для олівців з фігурою прикордонника із біноклем у руці. 1930-ті pp. Варіант розпису. Фігура прикордонника виконана за моделлю 1931 р. Фарфор, надглазурне криття. Збірка ВМДПНМ. 17. «Матрос 3 підзорною трубою в руках» («Червонофлотець»). 1931 р. Бісквіт, надглазурний розпис. Збірка А. А. Добровінського. 18. Підставка для олівців 3 фігурою матроса із гучномовцем. 1931 p. На підставці для олівців напис: «Шесть условий товарища Сталина - путь к победе». Фарфор, надглазурний розпис, позолота. Збірка А. А. Добровінського. 19. Підставка для олівців з фігурою спортсмена, що сидить. 1931 р. Фарфор, надглазурний розпис. Збірка А. А. Добровінського. 20. Підставка для олівців $з$ фігурою спортсмена, що сидить. 1931 р. Варіант розпису. Фарфор, надглазурний розпис. Збірка ВМДПНМ [11]. 21. Підставка для олівців 3 фігурою спортсмена, що сидить («Фізкультурник на спіралі»). Фарфор, розпис, полива. Збірка музею Дмитровського фарфорового заводу? [3, 483]. 22. Шахи «Соцзмагання» («Індустрія та сільське господарство»), 32 одиниці (16+16). 1932. Фарфор, надглазурний розпис. Збірка ВМДПНМ. 23. Настільна лампа «Комунизм есть советская власть плюс электрификация». 1931-1932 рр. Фарфор, надглазурний розпис. Приватна збірка. 24. Туркменські шахи. 1934. Фарфор, надглазурний розпис. Збірка А. А. Добровінського, збірка Державного музейного комплексу Москви «Кусково». 25. «Туркмен за листом». 
1933-1934 pp. Фарфор, надглазурний розпис. Збірка музею Дмитровського фарфорового заводу. 26. «Туркменка за читанням». 1933-1934 рр. Фарфор, надглазурний розпис. Збірка музею Дмитровського фарфорового заводу. На основі - авторський напис в масі. 27. Прес-папьє «Коммунар». 1930-ті pp. Бісквіт. Збірка Державного музейного комплексу Москви «Кусково» [13, с. 74 $75 ; 14$, c. 326-327].

У 1934 р. Дмитровський фарфоровий завод розпочав тиражний випуск шахмат за зразком виробленим Є. Трипільською. На цьому виробництві художниця створила багато шахових зразків різноманітної тематики й способу стилізації. Найбільше відомі шахові фігури «Індустріалізація та сільське господарство» (фарфор, ліплення, поліхромний розпис). Шахова група на тему «Сільське господарство» складається з наступного образного ряду: король мініатюрна тригранна стела з рельєфними зображеннями тракториста, колгоспного механізатора біля молотилки, цепної передачі й колосу пшениці. Висота 8,7 см. Пішак - скомпонований 3 реторти, колби й книги із формулою кислотно-азотного добрива та символізує хімізацію сільського господарства. Висота 3,8 см. Королева - кілька жниць під снопом, ладді - мають вигляд сховища під назвою «силос».

Шахові фігури на тему «Індустріалізація» складаються з наступних композицій: король - мініатюрна тригранна стела 3 рельєфними зображеннями сталевара біля доменної печі, верстатобудівника в цеху, інженера в лабораторії. Висота 7,8 см. Пішак скомпонований з лампочки, шматку вугелю й проводу та символізує електрифікацію народного господарства. Висота 3,8 см. Автор моделей - С. Трипільська, СРСР, Дмитровський фарфоровий завод у Вербілках, початок 1930-х рр. Набір шахів знаходиться нині у збірці Всеросійського музею декоративно-прикладного й народного мистецтва [9].

Ще в 1926-1927 рр. паралельно з творчою працею у фарфорі, мисткиня виконала статуї «Туркмен, що пише», «Туркменка, що читає», а також герб Туркменської РСР. 3 1933-1934 рр. також відомі iї, мабуть, ліплені з натури, парні статуетки туркменів у національному вбранні. Можливо С. Трипільська мала творче відрядження до цієї республіки. Створені після переламного 1932 р., ці сидячі фігурки туркменки за читанням книги й туркмена за письмом, розташовані на декорованих килимках, виконані досить реалістично в яскравій малиново-чорній гамі. Майстерна пластика перестає бути спрощеною, художниця намагається не стилізувати образи, а підкреслити психологію своїх екзотичних моделей. Дбайливо вимальовані візерунки взуття туркмена сприймаються як споріднені українській вишивці, а жовто-чорні торочки одягу туркменки підкреслюють крій, а комір нагадує гердан. Поступово скульптор відмовляється від «пролетарської еклектики» й повертається в річище обраного раніше власного напрямку «етнографічного натуралізму». 
Є. Трипільська 31928 р. була членом Спілки художників Азербайджану, пробувала реалізуватися і в річищі соцреалізму, панівного з 1932 р. 3 1932-1934 pp. постали барельєфи Леніна, Сталіна серед робочих нафтовиків (1939р.), Молотова, Кагановича, необхідні для фізичного виживання колишньої дворянки, якій довго не пробачали ії походження, а також барельєф Маяковського. 1936 р. датовано барельєфи й бюсти Шаумяна, Азізбекова, Джапарідзе, Фіолетова для оздоблення Музею Революції в Баку, 1938 р. - барельєф для кінотеатру імені Нізамі. 3 1930-х рр. відомі й скульптурні портрети С. Трипільської першої льотчиці-азербайджанки Мамедової, інженера Сугри Рагимової, надгробковий барельєф письменника Джафара Джабарли (обидва останні - 1939 р.), бюст комсомольця-орденоносця Слчієва, а також рельєфи архітектурних споруд, портрет грузинського поета Шота Руставелі (1939 р.) [25; 21; 19; 20] (Рис. 6).

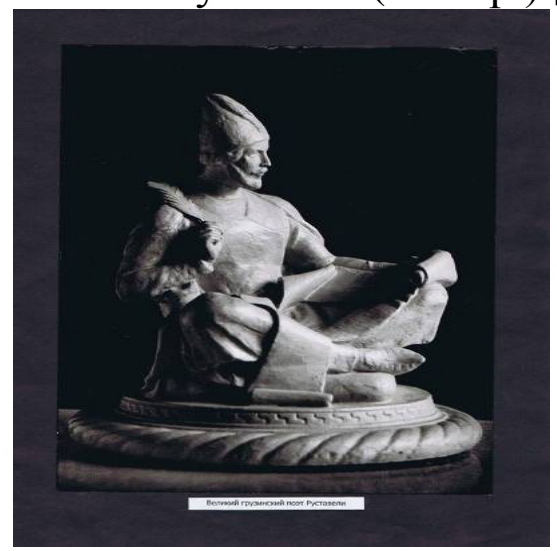

Рисунок 6. Скульптура грузинського поета Шота Руставелі авторства Єлизавети Трипільської. 1939 р. Світлина з родинного архіву Трипільських (США - Ізраїль).

У 1940-го р. скульпторка виконала низку робіт для інтер'єрів будівлі Ісмаїлії Азербайджанської Академії Наук (барельєфи та горельєфи «Землеробство», «Музика», «Прометей», «Наука»). У 1941-го р. - статую «Колгоспниця» для Самур-Дивичинського каналу. В азербайджанський період вона також працювала над монументальною статуєю Хуршид Бану Натаван в лоджії музею Нізами в Баку (1940р.), барельєфами великих композиторів для великої зали Держконсерваторії в Баку (всі - 1940 р.) та письменників-класиків для палацу Шаумяна в Баку (1942р.), погруддями офіційних діячів, зокрема, Аббасова та професора Топчибашева (обидва - 1943 р.), барельєфами Леніна та Сталіна на в’їзній арці в Шихово (1945р.), бюстом Героя Радянського Союзу Ахмедова (1947 р., був встановлений на батьківщині моделі), скульптурною групою «Перемога» (1949 р., Мінчегаур), барельєфом на фасаді будівлі театру Оперети (пізніше ТЮГу). Серед низки творів С. Трипільської недатованими лишилися бюсти Павлової, доктора О. Пассека. 1951 р. скульптор виконала останні роботи в фарфорі - «Біле золото» та «Натаван», про що зазначила у своїй автобіографії, датованій 7 липня 1956 р. [25; 21; 19; 20;23]. 
Померла С. Трипільська у Баку 1958 р. [18; 21].

Останне місце спочинку визначної опішнянки знаходиться в столиці Азербайджану. У скульпторки не було дітей, через череду потрясінь, починаючи з розстрілу батька Родіона Павловича на іï очах у власному маєтку 1918 р., коли вона ледве врятувалася втечею [19], ій не вдалося створити особисте родинне гніздечко. Проте, частину родинного архіву та колекції творів пластика зберігає кілька родин племінників і їх дітей та онуків, для яких вона була не лише рідною, а й духовно близькою людиною.

Найбільша колекція творів Слизавети Трипільської нині знаходиться в Державному музеї мистецтв імені Р. Мустафаєва в Баку, а також у приватних колекціях у діапазоні від України до Америки [22, с. 188-189]. У Росії ії твори зберігаються в Державному російському музеї, Кусково, Всеросійському музеї декоративно-прикладного й народного мистецтва, Музеї Дмитровського фарфорового заводу тощо [22]. Станкові скульптури та пам'ятники Єлизавети Трипільської прикрашали та прикрашають міста Скатеринбургу, Дніпра, Баку та Ашгабаду; скульптура малих форм та посуд авторки зберігається та експонується в музеях Опішного, Дніпра, Харкова, Москви, Баку [10], Нью-Йорку; іiі тиражні авторські вироби з порцеляни є надбанням світового промислового мистецтва XX ст.

Висновки. Отже, європейсько-азійські трансформації в творчості Єлизавети Трипільської пов'язані зі спадком формотворення українського гончарства Полтавського краю; виразними імпульсами французького імпресіонізму в скульптурі, що спирався на напрацювання видатного пластика Огюста Родена та його школи; розвитком лінії пластичного моделювання так званих «екзотів» у російській порцеляні, поглибленої в добу «міріскусників» та арт деко на початку XX ст. творчістю Аліси Брускетті-Мітрохіної та сестер Наталі й Олени Данько; мотивами колористичних рішень таджикських килимів та вишивки; традиційного азербайджанського мистецтва 3 векторами до турецько-османської та кавказької культури.

Перспективи подальших досліджень варто пов'язувати зі створенням каталогу творів Слизавети Трипільської.

\section{Список використаних джерел}

1. Асеева Н. Ю. Украинское искусство и европейские художественные центры (конец XIX - начало XX века) / Н. Ю. Асеева. - Киев : Наук. думка, 1989. - 199 c.

2. Андреева Л. Советский фарфор. 1920-1930 годы / А. Андреева. Москва : Совет. художник, 1975. - 339 с. 
3. Буряк В. В. Нотатки до атрибуції експоната ДІМ - бюста Д.І.Яворницького [Електронний ресурс] / В. В. Буряк. - Режим доступу : https://ru.museum.dp.ua/article043.html. - Назва з екрана.

4. Вербилки. История фарфорового завода Ф. Я. Гарднера / [Мачульский Е. Н., Зилов А. А., Кравцова Ю. Н.]. - Москва : Авангард, 2005. - 503 с.

5. Ленинградский государственный архив Октябрьской революции и социалистического строительства. Ф. 1181, св. 46, оп. 12, ед. хр. 5, с. 9.

6. Німенко А. В. Українська скульптура другої половини XIX - початку ХХ ст. - Київ, 1963. - 127 с.

7. Новрузова Д. Творчество Е. Р. Трипольской : к 100-летию со дня рождения / Д. Новрузова // Искусство. - 1983. - №3. - С. 83.

8. Носович Т. Н. Государственный фарфоровый завод : 1904-1944 / под. науч. ред. В. В. Знаменова / Т. Н. Носович, И. П. Попова. - Санкт-Петербург : Санкт-Петербург Оркестр ; Москва : ОАО Иван Федоров, 2005. - 751 с.

9. Про Холодовського М. І. [Електронний ресурс]. - Режим доступа: http://www.histpol.pl.ua/person/pers-19/pers19-026.htm. - Назва з екрана.

10. Форум для коллекционеров антиквариата: Трипольская Елизавета Родионовна. - Режим доступа: http://www.antique-salon.ru/forum/lofiversion/index. php/t34625.html. - Загл. с экрана.

11. Пчілка Олена. Українська скульпторка Катерина [Єлизавета - О. Ш.] Трипольська / О. Пчілка // Рідний край. - 1913. - Ч. І. - С. 9-11.

12. Русский фарфор. 250 лет истории : каталог / авт.-сост. Л. В. Андреева. Москва : Авангард, 1995. - 94 с.

13. Самецкая Э. Советский агитационный фарфор: справочникопределитель / Э. Самецкая. - Москва : Collector's Books : IP Media Inc., 2004. $477 \mathrm{c}$.

14. Самецкая Э. Б. Советский фарфор 1920-1930-х годов в частных собраниях Санкт-Петербурга : каталог / Э. Самецкая. - Москва : IP-Media, 2005. $-352 \mathrm{c}$.

15. Світленко С. І. Дмитро Яворницький: вчений та педагог в українському інтелектуальному співтоваристві : монографія. - Дніпропетровськ : Вид-во «Лiра», 2015. - $312 \mathrm{c}$.

16. Советский художественный фарфор 1918-1923 : каталог / Гос. музей керамики и «Усадьба Кусково XVIII века» ; [кат. сост. Б. И. Алексеевым и др.]. - Москва : Изд-во Акад. художеств СССР, 1962. - 115 с.

17. Советское декоративное искусство : Фарфор. Фаянс. Стекло. Материалы и документы, 1917-1932 / Акад. художеств СССР, НИИ теории 
и истории изобразит. искусств, Центр. гос. арх. нар. хоз-ва СССР ; авт.-сост. И. А. Пронина и др. - Москва : Искусство, 1980. - 339 с.

18. Трипільська Є. Р. [Електронний ресурс]. - Режим доступу : https://uk. wikipedia.org/wiki/\%D0\%A2\%D1\%80\%D0\%B8\%D0\%BF\%D1\%96\%D0\%BB\%D1 $\% 8 \mathrm{C} \% \mathrm{D} 1 \% 81 \% \mathrm{D} 1 \% 8 \mathrm{C} \% \mathrm{D} 0 \% \mathrm{BA} \% \mathrm{D} 0 \% \mathrm{~B} 0 \_\% \mathrm{D} 0 \% 84 \% \mathrm{D} 0 \% \mathrm{BB} \% \mathrm{D} 0 \% \mathrm{~B} 8 \% \mathrm{D} 0 \%$ B7\%D0\%B0\%D0\%B2\%D0\%B5\%D1\%82\%D0\%B0_\%D0\%A0\%D0\%BE\%D0\%BC $\% \mathrm{D} 0 \% \mathrm{~B} 0 \% \mathrm{D} 0 \% \mathrm{BD} \% \mathrm{D} 1 \% 96 \% \mathrm{D} 0 \% \mathrm{~B} 2 \% \mathrm{D} 0 \% \mathrm{BD} \% \mathrm{D} 0 \% \mathrm{~B} 0$ - Назва з екрана.

19. Трипольская Вероника Олеговна. Уточнения по биографии Е. Р. Трипольской. Переписка с О. В. Школьной. 2011 г.

20. Трипольская Елизавета Родионовна // Личный архив О. В. Трипольского; в 60-ти лист. - Рукопись.

21. Трипольская Елизавета Родионовна - скульптор (1881-1958). [Електронний ресурс]. - Режим доступу : https://www.ourbaku.com/index.php/. Загл. с экрана.

22. Ханко В. Словник митців Полтавщини / В. Ханко. - Полтава : ВАТ Вид-во «Полтава», 2002. - 203 с.

23. Ханко В. Трипільська С. Р. / В. Ханко // УРЕ. - Київ, 1984. - Т. 11. KH. I. - C. 347.

24. Холодовський М. I. [Електронний ресурс]. - Режим доступу : http://www.histpol.pl.ua/ru/poltavskij-rodoslov/alfavitnyj-ukazatel-rodov/spisokrodov-r?id=3341. - Назва з екрана.

25. Художники України : енциклопед. довідник / Акад. мистецтв України, Ін-т проблем сучасного мистецтва АМУ; редкол. : В. Д. Сидоренко (голова) та ін. - Київ : Інтертехнологія, 2006. - Вип. 1 - 640 с.

26. Центральный государственный архив народного хозяйства СССР. Ф. 8013, оп. 1 , д. 528в, л. 43, 44.

27. Черный Н. В. Фарфор Вербилок : из истории рус. и советского фарфора / Н. В. Черный. - Москва : Изобраз. искусство, 1970. - 295 с.

\section{References}

1. Aseeva, N. (1989). Ukrainian art and European art centres (the late $19^{\text {th }}$ early $20^{\text {th }}$ century). Kyiv: Naukova dumka.

2. Andreeva, L. (1975). Soviet porcelain. 1920's-1930's. Moscow: Sovetskiy khudozhnik.

3. Andreeva, L. ed. (1995). Russian porcelain. 250 years of history: the Catalogue. Moscow: Avangard, pp. 86-87.

4. Alekseev, B. ed. (1962). Soviet art porcelain in 1918-1923: the Catalogue. Moscow: Akademiya krugosvet SSSR. 
5. Buriak, V. (2017). Notes on the attribution of the exhibit DIM D. Yavornytskyi's bust. Aailable at: <https://ru.museum.dp.ua/article043.html> [Accessed on 12 September, 2017].

6. Zilov, A., Kravtsova Yu., Machul'sky E. (2005). Verbilki. The history of F. Gardner porcelain factory. Moscow: Avangard.

7. The Leningrad state archive of the October revolution and socialist architecture. Fund 1181, parcel 46, inventory 12, unit of storage 5, p. 9.

8. Nimenko, A. (1963). Ukrainian sculpture of the late $19^{\text {th }}$ - early $20^{\text {th }}$ centuries. Kyiv: Akademiia nauk Ukrainskoi RSR.

9. Novruzova, D. Ye. Tripolskaya's creative work (1983). To the $100^{\text {th }}$ anniversary of birth. Iskusstvo [Art], no 3, p. 83.

10. Nosovich, T. (2005). State Porcelain Factory: 1904-1944. Moscow: St. Petersburg.

11. On Holodovsky M. Available at: <http://www.histpol.pl.ua/person/pers19/pers19-026.htm.http://www.histpol.pl.ua/person/pers-19/pers19026.htm.> [Accessed on 10 September, 2017].

12. Forum for collectors of antiques: Tripolskaya Yelizaveta Rodionovna. Availableat: <http://www.antique-salon.ru/forum/lofiversion/index.php/t34625.html> [Accessed 25.06.2009].

13. Pchilka, O. (1913). Ukrainian sculptor Katerina. Ridniy krai, part 1., pp. 9-11.

14. Sametskaja, E. (2004). Soviet agigational porcelain: the reference bookdeterminant. Moscow: Collector's Books: IP Media Inc.

15. Sametskaja, E. (2005). Soviet porcelain of the 1920's-1930's in private collections in St. Petersburg: the catalog. Moscow: IP-Media.

16. Svitlenko, S. (2015). Dmytro Yavornytskyi: the scientist and the teacher in the Ukrainian intellectual association: the monography. Dnipropetrivsk: Lira.

17. Pronina, I. Eds (1980). Soviet decorative art : Porcelain, Faience, Glass. Materials and documents. 1917-1932. Moscow: Akad. khudozhestv SSSR.

18. Trypilska Y. Available at : <https://uk.wikipedia.org/wiki/\%D0\%A2\%D1 \%80\%D0\%B8\%D0\%BF\%D1\%96\%D0\%BB\%D1\%8C\%D1\%81\%D1\%8C\%D0\%BA \%D0\%B0_\%D0\%84\%D0\%BB\%D0\%B8\%D0\%B7\%D0\%B0\%D0\%B2\%D0\%B5\% D1\%82\%D0\%B0_\%D0\%A0\%D0\%BE\%D0\%BC\%D0\%B0\%D0\%BD\%D1\%96\%D0 $\% \mathrm{~B} 2 \% \mathrm{D} 0 \% \mathrm{BD} \% \mathrm{D} 0 \% \mathrm{~B} 0 .>$ [Accessed on 10 September, 2017].

19. Tripolskaya Veronika Olegovna. Specifications on the biography of Ye. Tripolskaya. Correspondence from O. Shkolna. 2011.

20. Tripolskaya Yelizaveta Podionovna. «The autobiography» from archive of Oleg Vladimirovich Tripolsky, 2013. 
21. Tripolskaya Yelizaveta Podionovna - the sculptor (1881-1958). Available at: <https://www.ourbaku.com/index.php/> [Accessed on 10 September, 2017].

22. Hanko, V. (2002). The dictionary of artists of Poltava region. Poltava: Vydavnytstvo Poltava.

23. Hanko, V. (1984). Trypilska Ye. Ukrainska Radianska entsyklopediia [Ukrainian Soviet Encyclopedia], vol. 11. p. 347.

24. Holodovskyi, M. (2017) Available at: <http://www.histpol.pl.ua/ru/poltavs kij-rodoslov/alfavitnyj-ukazatel-rodov/spisok-rodov-r?id=3341> [Accessed on 10 September, 2017].

25. Sydorenko, V. Eds. (2006). Artists of Ukraine: the Encyclopaedic dictionary. vol. 1. Kyiv: Intertekhnolohiia.

26. The central state archive of national economy of the USSR. Fund 8013, inventory 1 , case 528B, sheet 43, 44 .

27. Chernyj, N. (1970). Porcelain of Verbilki. Moscow: Izobrazitel'noe iskusstvo.

(C) Школьна О. В., 2017 